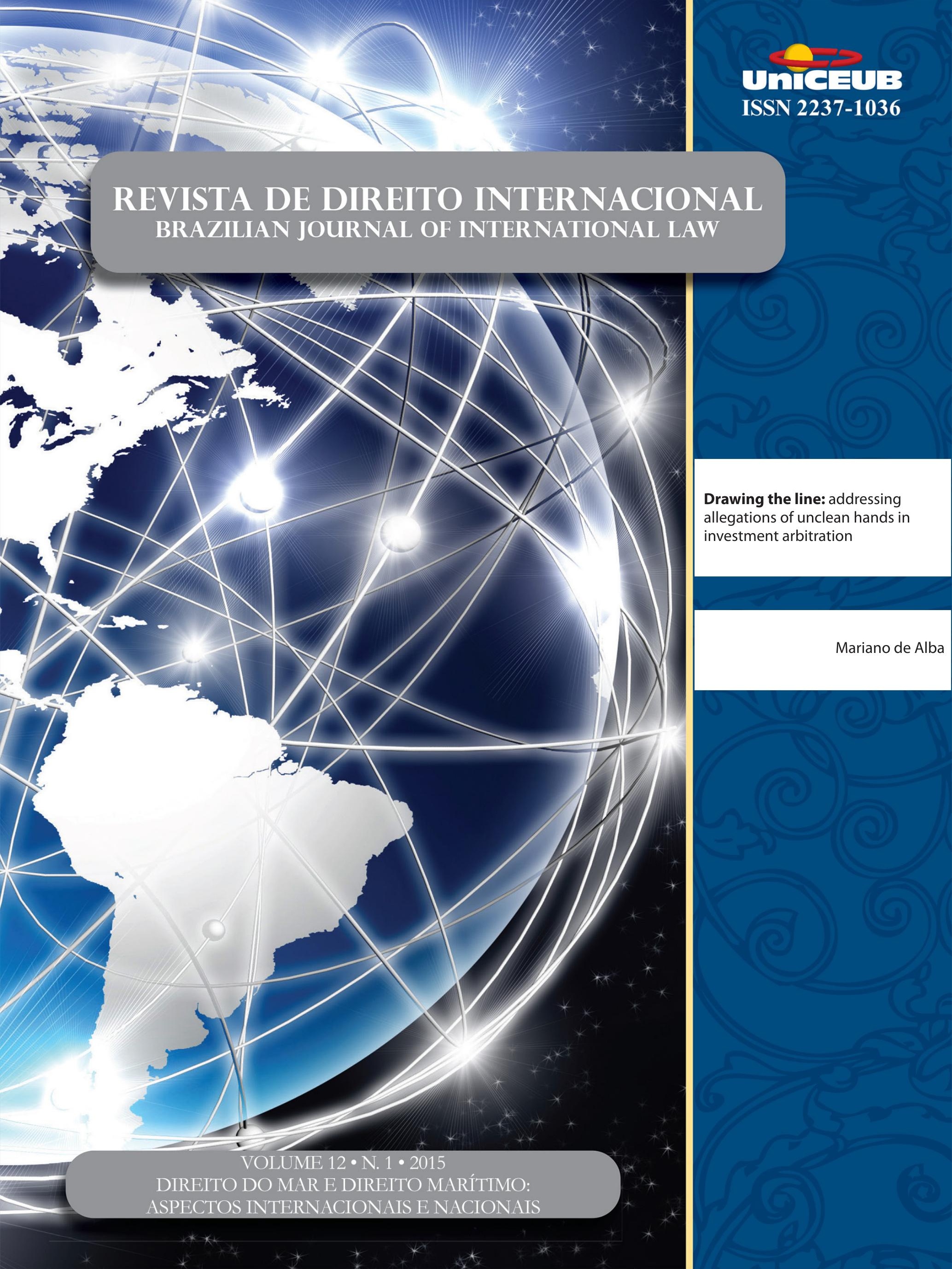




\section{Sumário}

\section{Crônicas}

CRôNICAS DA ATUALIDADE do DiREITO INTERNACIONAL ........................................................ 2

Nitish Monebhurrun (org.)

Towards a european regulation of the importation of conflict minerals?..... 2

Nitish Monebhurrun

Keeping up with the terrorists: the EU's proposed Passenger Name Records (PNR) Directive \& european security

Eshan Dauhoo

A histórica reaproximação de Cuba e EUA

Erika Braga

A contextualização da atual reivindicação da Grécia para receber indenizações por atos da Alemanha durante a Segunda Guerra Mundial . .10

Natália da Silva Gonçalves

José Eduardo Paiva Miranda de Siqueira

Crônicas da jurisprudência do Direito Internacional (CIJ/ITLOS): Decisões da Corte Internacional de Justiça e do Tribunal Internacional Sobre o Direito do Mar .14

Nitish Monebhurrun (Org.)

Corte Internacional de Justiça

Estudo da decisão da Corte Internacional de Justiça no caso Croácia v. Servia (03/02/2015) .14

Liziane Paixão Silva Oliveira e Maria Edelvacy Marinho

Questões relacionadas com a apreensão e detenção de certos documentos e dados: (Timor Leste c. Austrália) - O reconhecimento do retorno de uma relação amigável entre Timor-Leste e Austrália e a nova decisão da CIJ, 6 de maio de 2015 . 20

Gleisse Ribeiro Alves

Tribunal Internacional sobre Direito do Mar

Caso da delimitação da fronteira marítima entre o Gana e a Costa do Marfim no Oceano Atlântico: medidas cautelares $(25 / 04 / 2015)$

Nitish Monebhurrun

Comentário à Opinião Consultiva 21 do Tribunal Internacional para o Direito Do Mar [02/04/2015] (Responsabilidade do Estado de Bandeira pela pesca ilícita, não declarada ou não regulamentada) ...............25

Carina Costa de Oliveira 
CRÔNICAS DO DIREITO INTERNACIONAL DOS INVESTIMENTOS

Nitish Monebhurrun (Org.)

A inclusão da responsabilidade social das empresas nos novos Acordos de Cooperação e de Facilitação dos Investimentos do Brasil: uma revolução 33

Nitish Monebhurrun

\section{O Direito do Mar Perante as JuRisdições INTERnacionais}

CoAstal States' Rights IN THE MARITIME AREAS UNDER UNCLOS .40 Tullio Treves

TACKling illegal, unregulated And unReported Fishing: THE ITLOS Advisory OpINION on Flag State Responsibility for IUU fishing AND THE PRINCiple of DUE DiligenCE ...50 Victor Alencar Mayer Feitosa Ventura

REFLEXões PROVENIENTES do DisSENSO: UMA ANÁLISE CRÍtica A RESPEITO do CASO Austrália versus Japão Perante a Corte InTERnacional de JustiçA .......................................68 Luciana Ferna ndes Coelho

Os TRATADOS INTERNACIONAIS DE DIREITO DO MAR E SEUS EFEITOS SOBRE TERCEIROS ESTADOS ..... 86 Tiago V. Zanella

\section{InStRumentos JURÍdicos PARA A GeStÃo do MAR}

OS LIMITES DOS TERMOS BEM PÚBLICO MUNDIAL, PATRIMÔNIO COMUM DA HUMANIDADE E BENS COMUNS PARA DELIMITAR AS OBRIGAÇÕES DE PRESERVAÇÃO DOS RECURSOS MARINHOS 109 Carina Costa de Oliveira e Sandrine Maljean-Dubois

Os limites do PLANEJAMENTO DA OCUPAÇÃo SUSTENTÁVEL DA ZONA COSTEIRA BRASILEIRA ... 126 Carina Costa de Oliveira e Luciana Coelho

CORRENDO PARA O MAR NO ANTROPOCENO: A COMPLEXIDADE DA GOVERNANÇA DOS OCEANOS E A ESTRATÉGIA BRASILEIRA DE GESTÃO DOS RECURSOS MARINHOS 
A comissão de limites da Plataforma continental (CLPC) E Os DESAFios Na delineaÇÃo DAS PLATAFORMAS CONTINENTAIS ESTENDIDAS................................................... 170

Alexandre Pereira da Silva

\section{A PROTEÇÃo DO MEIO AMBIENTE MARINHO}

O gRANDE JOGo do ÁrTiCo: REFLEXões COM BASE NA PERSPECTIVA DE EXPLORAÇão ECONÔMICA

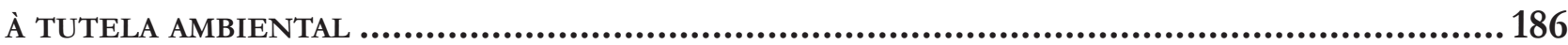

Fernando Rei e Valeria Cristina Farias

Instrumentos Públicos e Privados para a reparação do dano ambiental causado por DERRAMAMENTO DE ÓLEO NO MAR SEM ORIGEM DEFINIDA: AS MANCHAS ÓRFÃS

Renata Brockelt Giacomitti e Katya R. Isaguirre-Torres

O DIREITO INTERNACIONAL PRIVADO E A RESPONSABILIDADE CIVIL EXTRACONTRATUAL POR DANOS AMBIENTAIS CAUSADOS POR TRANSPORTES MARÍTIMOS À LUZ DO DIREITO BRASILEIRO ....... 217 Inez Lopes

A NECESSIDADE DE REPENSAR OS MECANISMOS DE RESPONSABILIDADE AMBIENTAL EM CASO DE riscos de VAZamento de PETRóleo Na Zona Econômica Exclusiva do BrasiL

Marcelo D. Varella

\section{Problemáticas do Direito Marítimo}

A FisCALIZAÇão SANitÁRIA DAS EMBARCAÇÕES EM ÁGUAS JURISDICIONAIS BRASILEIRAS: NOTAS aCERCA da (IN)efetividade da Súmula 50 da AGU

Joedson de Souza Delgado e Ana Paula Henriques da Silva

A IMO E A REPRESSÃo AO ROUBO ARMADO CONTRA NAVIOS: DA RETÓRICA INTERNACIONAL À COOPERAÇÃO REGIONAL

André Panno Beirão e Charles Pacheco Piñon

\section{O Direito do Mar diante da Pirataria}

O DIREITO INTERNACIONAL EM FACE DA PIRATARIA EM ALTO-MAR: UMA PERSPECTIVA CRÍTICA.289 Maiquel Ângelo Dezordi Wermuth e Rafaela Correa 
Pirataria marítima: A EXPERIÊnCIA Somália

Eduardo Augusto S. da C. Schneider

\section{Temas Gerais}

DRAWING THE LINE: ADDRESSING ALLEGATIONS OF UNCLEAN HANDS IN INVESTMENT ARBITRATION*

Mariano de Alba

Para Que Serve a história do Direito internacional?

George Rodrigo Bandeira Galindo

As interferências entre a Política Externa e de Segurança Comum Europeia (Pesc) e O DiREITO DAS NaÇões UNIDAS

Leonardo de Camargo Subtil

Introdução Às regras de aplicaÇão da Convenção da ONU Sobre Contratos de ComPRA E VENDA INTERNACIONAL DE MERCADORIAS E O DIREITO INTERNACIONAL PRIVADO BRASI-

LEIRO 380

Paul Hugo Weberbauer e Eugênia Cristina Nilsen Ribeiro Barza

A REgulaÇÃo das EMPRESAS TRANSNACIONAIS ENTRE AS ORDENS JURÍDICAS ESTATAIS E NÃO ESTATAIS.

Mateus de Oliveira Fornasier e Luciano Vaz Ferreira

OUtLAWING HATE SPEECH IN DEMOCRATIC STATES: THE CASE AGAINST THE INHERENT LimitAtions doctrine concerning Article 10 (1) of the European Convention on Human

Rights 416

Stefan Kirchner 


\title{
Drawing the line: addressing allegations of unclean hands in investment arbitration*
}

Mariano de Alba**

\begin{abstract}
The idea underlying the clean hands doctrine is that the lawfulness of the investor's conduct is a pre-condition for the bestowal of jurisdiction upon the arbitral tribunal. However, this paper argues that the application of such doctrine - in the investment arbitration context - should not mean that States have an unlimited right to pursue the dismissal of a claim following an investor's failure to comply with the host State's law. Thus, there are two factors that an investment arbitration tribunal should take into account when confronted with allegations of unlawful acts committed by an investor in the establishment or development of its investment. First, the tribunal should assess the type and the degree of the violation of the law committed by the investor; and second, the tribunal should evaluate the relationship between the investor's wrongdoing and the State's conduct in connection with the commission and subsequent treatment of such infraction. In short, this paper provides an analytical framework for tribunals to follow in cases where the clean hands doctrine is invoked.
\end{abstract}

Keywords: international investment law, clean hands doctrine, investor's duties

\section{INTRODUCTION}

An investor wants to establish an enterprise in a foreign country. It seeks the assistance of legal counsel to comply with the complex regulatory framework to commence operations. It makes an initial investment of US\$10 million. As time goes by, the investor reinvests the profits in the new foreign company, purchasing additional equipment and technology.

Later on the host State engages in a series of actions that, in the view of the investor, breach the obligations of an existent bilateral investment treaty ("BIT") between the host State and the country where the investor comes from. Once the case is brought before an international investment tribunal, the host State argues that the investor should not be allowed to proceed with its claims, since in the establishment (or development) of the investment the investor contravened the host State's law.

Should the tribunal uphold that defense? Which is the correct approach that arbitrators should take in order to reach a decision in relation to this issue? Such questions imply a broader inquiry: should investment arbitration tribunals apply the clean hands doctrine?

In simple terms, the clean hands doctrine implies that a party will not be allowed to bring a claim if it is proven that it was involved in an unlawful 
act in relation to its claim. ${ }^{1}$ For several years, investment arbitration tribunals have encountered (and sometimes applied) the idea underlying this doctrine. ${ }^{2}$ Presumably, States began invoking such principle since it was already known under public international law, ${ }^{3}$ which in turn adapted it from early Roman ${ }^{4}$ and common law principles. ${ }^{5}$

However, the application of the doctrine in the investment arbitration context has not been free of discussion and controversy. ${ }^{6}$ The tribunal in Niko Resources

1 Andrew D. Mitchell, M. Sornarajah and Tania Voon, Good Faith and International Economic Law, Oxford University Press, 2015, p. 2930.

2 See, for example: Inceysa Vallisoletana, S.L. v. Republic of El Salvador, ICSID Case No. ARB/03/26, Award (2 August 2006); Fraport AG Frankfurt Airport Services Worldwide v. Philippines, ICSID Case No. ARB/03/25, Award (16 August 2007); Plama Consortium Ltd. v. Republic of Bulgaria, ICSID Case No. ARB/03/24, Award (27 August 2008); Phoenix Action, Ltd. v. The Czech Republic, ICSID Case No. ARB/06/5, Award (15 April 2009).

3 For example, Judge Hudson referred to the principle in the Case Concerning the Diversion of Water from the River Meuse (Netherlands v. Belgium), Separate Opinion of Judge Hudson, Judgment of 28 June 1937, PCIJ Series A/B, No. 70. See also Bin Cheng, General Principles of Law as Applied by International Courts and Tribunals, Cambridge University Press, 1994, p. 155; Ian Brownlie, Principles of Public International Law, Oxford University Press, 2008, p. 503.

4 Some Roman law principles which can be understood to be the genesis of the doctrine are the following: ex turpi causa non oritur actio ("an action does not arise from a dishonorable cause"); nemo auditur propriam turpidunem allegans ("no one can be heard to invoke his own turpitude"); and nemo ex suo delicto meliorem suam conditionem est facit ("no one can perfect his condition by a crime"). Thus, the doctrine has been no stranger in civil law systems. See Inceysa Vallisoletana, S.L. v. Republic of El Salvador, supra note 2, para 240.

5 Originally an equitable doctrine in common law systems, it was adopted by Chief Baron Eyre of the English Court of Exchequer (which had equity powers) in Dering v. Earl of Winchelsea, (1787) 29 Eng. Rep. 1184 (Ch.) 1186; 1 Cox Eq. Cas. 318, 319-20. In U.S. courts, it has been applied since the American Revolution. See T. Leigh Anenson, Limiting Legal Remedies: An Analysis of Unclean Hands, Kentucky Law Journal, Vol. 99, 2010, p. 63-64.

6 See Bernardo Cremades, Corruption and Investment Arbitration, in Global Reflections on International Law, Commerce and Dispute Resolution: Liber Amicorum in Honour of Robert Briner, Gerald Aksen et al eds., 2005, p. 203; Mohamed Abdel Raouf, How Should International Arbitrators Tackle Corruption Issues? ICSID Review (2009) 24 (1), p. 116-136; Bernardo M. Cremades, Investment Protection and Compliance with Local Legislation, ICSID Review (2009) 24 (2); p 557-564; Carolyn B. Lamm, Hansel T. Pham, and Rahim Moloo, Fraud and Corruption in International Arbitration, in M.A. FernandezBallesteros and David Arias, Liber Amicorum Bernardo Cremades, Wolters Kluwer, 2010, p. 711-715; Andrea J. Menaker, The Determinative Impact of Fraud and Corruption on Investment Arbitrations, ICSID Review (2010) 25 (1), p. 67-75; Richard Kleindler, Corruption in International Investment Arbitration: Jurisdiction and the Unclean Hands Doctrine, in Between East and West: Essays in Honour of Ulf Franke, Kaj Hobér et al eds., Juris, 2010, p. 309-327; Rahim Moloo, A Comment v. Bangladesh recognized very recently that the precise content of the clean hands doctrine was "ill defined." Nowadays, no one seems to contest that the establishment and development of an investment presupposes an obligation for the investor to comply with the host State's laws and regulations. ${ }^{8}$ Nevertheless, there can be cases when the host State, by action of one of its agents, is involved in the violation of the host State's law. The relevant authorities may also not protest such violation until the investor brings its case before the investment arbitration tribunal. ${ }^{9}$ Should the State be allowed under such scenarios to invoke the clean hands doctrine?

Some have argued that it is unfair to assume that

on the Clean Hands Doctrine in International Law, TDM 1 (2011); Available at: www.transnational-dispute-management.com; Kevin Lim, Upholding Corrupt Investors' Claims Against Complicit or Compliant Host States - Where Angels Should Not Fear to Tread, Yearbook on International Investment Law and Policy 2011-2012, Oxford University Press, p. 601-679; Aloysius Llamzon, Corruption in International Investment Arbitration, Oxford University Press, 2014; p. 238-281 and p. 493-513; Zachary Douglas, The Plea of Illegality in Investment Treaty Arbitration, ICSID Review (Winter 2014) 29 (1), p. 155-186; Carolyn B. Lamm, Brody K. Greenwald, and Kristen M. Young, From World Duty Free to Metal-Tech: A Review of International Investment Treaty Arbitration Cases Involving Allegations of Corruption, ICSID Review (Spring 2014) 29 (2), p 328-349; Joe Tirado, Matthew Page, and Daniel Meagher, Corruption Investigations by Governmental Authorities and Investment Arbitration: An Uneasy Relationship, ICSID Review (Spring 2014) 29 (2), p. 493-513; Aloysius Llamzon, The State of the "Unclean Hands" Doctrine in International Investment Law: Yukos as both Omega and Alpha, ICSID Review (Spring 2015) 31 (1), p. 1-15; Brody Greenwald, The Viability of Corruption Defenses in Investment Arbitration When the State Does Not Prosecute, EJIL: Talk! Blog of the European Journal of International Law, April 15, 2015, Available at: http://www.ejiltalk. $\mathrm{org} /$ the-viability-of-corruption-defenses-in-investment-arbitrationwhen-the-state-does-not-prosecute/

7 Niko Resources Ltd. v. Bangladesh, ICSID Case No. ARB/10/11, Decision on Jurisdiction (19 August 2013), para 477.

8 CDC Group, Code of Responsible Investing, available at: www.cdcgroup.com/PageFiles/149/cdcinvestmentcode.pdf. CDC is the UK's Development Finance Institution (DFI), wholly owned by the UK Government. It is the world's oldest DFI with a history of making successful investment in businesses which have become industry leaders thereby having enormous impact on the private sector in their country and region as well as improving the lives of many individuals. Since 2012, it has applied the same standards, as defined in their Code of Responsible Investing, to CDC's own direct debt and equity investments. Schedule 3 of the Code of Responsible Investing provides that every business in which CDC's capital is invested will operate in compliance with applicable local and national laws including laws covering environmental impacts, labor rights, social issues, corporate governance and those intended to prevent extortion, bribery, corruption and financial crime.

9 See Tokios Tokelés v. Ukraine, ICSID Case No. ARB/02/18, Decision on Jurisdiction (29 April 2004), para 86; Técnicas Medioambientales Tecmed, S.A. v. The United Mexican States, ICSID Case No. $\mathrm{ARB}(\mathrm{AF}) / 00 / 2$, Award (29 May 2003), para 149. 
any evidence of illegality must lead an arbitration tribunal to deny an investor its right to bring a claim. ${ }^{10}$ On the other hand, several tribunals that have encountered this type of issue have upheld the principle; with one of them concluding that "no legal system based on rational grounds allows the party that committed a chain of clearly illegal acts to benefit from them". ${ }^{11}$ The mere reference to a "chain of clearly illegal acts" appears to reveal that the tribunal in Inceysa v. El Salvador had in mind something more than a specific violation of the host State's law.

Against such background, this paper argues that States should not have an unlimited right to invoke the clean hands doctrine following an investor's failure to comply with the host State's law. ${ }^{12}$ For such purposes, this article will first set out what type of violations of the law should allow a State to invoke such doctrine. In this sense, it will claim that only in cases of fundamental breaches (such as in instances of corruption, fraudulent misrepresentation or deliberate violations of legal provisions) should an arbitral tribunal consider the application of the doctrine. ${ }^{13}$ However, even in such cases, the tribunal should only proceed to deny protection to an investment after considering the investor's wrongdoing against the host State's conduct.

This means that, based on the principle of estoppel $^{14}$, if the State is involved in the commission of the unlawful act it should not be able to rely on the doctrine and the tribunal should uphold its jurisdiction. Furthermore, a State should also not be able to successfully invoke the clean hands doctrine if it knew of the unlawful act but did not protest or prosecute its commission within its own legal order. In such cases, I argue that

10 See Alison Ross, Should "clean hands" be a factor in investment arbitration?, Global Arbitration Review, October 30, 2009, Available at: http://globalarbitrationreview.com/news/article/19249/

11 Inceysa Vallisoletana, S.L. v. Republic of El Salvador, supra note 2, para 244.

12 Kevin Lim, Upholding Corrupt Investors' Claims Against Complicit or Compliant Host States - Where Angels Should Not Fear to Tread, supra note 6, p. 668; Alison Ross, Should "clean hands" be a factor in investment arbitration?, supra note 10.

13 See, Metal-Tech Ltd v. The Republic of Uqbekistan, ICSID Case No. ARB/10/3, Award (4 October 2013); World Duty Free Company Limited v. The Republic of Kenya, ICSID Case No. ARB/00/7, Award (4 October 2006); Inceysa Vallisoletana, S.L. v. Republic of El Salvador, supra note 2; Plama Consortium Ltd. v. Republic of Bulgaria, supra note 2; Fraport AG Frankfurt Airport Services Worldwide v. Philippines, supra note 2 .

14 James Crawford, Brownlie's Principles of Public International Law, Oxford University Press, 2012, p. 420-421. the involved State acquiesced ${ }^{15}$ to such illegal conduct and therefore the assessment of the unlawful conduct should be conducted in the merits phase of the dispute.

The invocation of the clean hands doctrine by a State requires an especially meticulous examination of the facts and the applicable law by the arbitration tribunal. It is in the interest of the legitimacy of investor-State dispute settlement and the rule of law that a tribunal applies the analytical framework herein proposed.

\section{The CLEAN HANDS DOCTRINE IN INVESTMENT ARBITRATION}

As a principle of equitable origin, investment arbitration tribunals have been careful not to apply the clean hands doctrine without invoking a specific basis in the corresponding applicable law to the case at hand. ${ }^{16}$ Thus, the doctrine has been recognized (and embodied) in at least two distinct forms. First, in the express text of some BITs, which require that any investment be made in compliance with the laws and regulations of the host State. ${ }^{17}$ Second, as a general principle of international law ${ }^{18}$, meaning that the doctrine can be applied

15 Aloysius Llamzon, Corruption in International Investment Arbitration, supra note 6, p. 272-275.

16 See, Inceysa Vallisoletana, S.L. v. Republic of El Salvador, supra note 2; Fraport AG Frankfurt Airport Services Worldwide v. Pbilippines, supra note 2; Plama Consortium Ltd. v. Republic of Bulgaria, supra note 2; Phoenix Action, Ltd. v. The Czech Republic, supra note 2.

17 See Article 1.1, Agreement between the Federal Republic of Germany and the Republic of Philippines for the Promotion and Reciprocal Protection of Investments, available at http://investmentpolicyhub.unctad.org/; Article 2, Agreement between the Islamic Republic of Pakistan and the Republic of Turkey Concerning the Reciprocal Promotion and Protection of Investments, available at http://investmentpolicyhub.unctad.org/; Article 2, Agreement on Encouragement and Reciprocal Protection of Investments between the Kingdom of the Netherlands and the Czech and Slovak Federal Republic, available at http://investmentpolicyhub.unctad. org/.

18 This author acknowledges that the tribunal in Yukos Universal Limited (Isle of Man) v. Russian Federation (See Hulley Enterprises Limited (Cyprus), Veteran Petroleum Limited (Cyprus) and Yukos Universal Limited (Cyprus) v. Russian Federation, PCA Case No. AA226-28, Final Awards (18 July 2014), para 1358) held that it was not persuaded of the existence of a general principle of law recognized by civilized nations that would bar an investor from making a claim before an arbitral tribunal under an investment treaty because it has so-called "unclean hands". However, this author begs to differ. The members of the Advisory Committee of Jurists who prepared the draft of the PCIJ Statute, which led to the ICJ Statute, were divided as to the nature of the principles that may be invoked under Article 38(1)(c). Neverthe- 
even absent a reference to such requirement in the text of the BIT. ${ }^{19}$

In relation to the first scenario, some BITs include, in their definition of investment, the caveat that for an investment to exist, it has to be made in accordance with the law of the State that is host to such investment. ${ }^{20}$ For instance, the Argentina-Canada BIT, defines investment as:

Any kind of asset defined in accordance with the laws and regulations of the Contracting Party in whose territory the investment is made, held or invested either directly, or indirectly through an investor of a third State, by an investor of one Contracting Party in the territory of the other Contracting Party, in accordance with the latter's laws. ${ }^{21}$

Thus, when such requirement is included in the relevant BIT and tribunals find that the investor did not comply with the law of the host State, tribunals have decided that they do not have jurisdiction ratione materiae

less, the principles in question were understood to be those which can be derived from a comparison of the various systems of municipal law, and the extraction of such principles as appear to be shared by all, or a majority of them. Considering that the idea underlying the clean hands doctrine has been recognized in both common and civil law systems since ancient times through several legal maxims, I believe that it would very difficult to conclude that the clean hands doctrine does not constitute a principle derived from the municipal law of at least a majority of the States of the international community. Thus, recognizing that the Yukos tribunal was limited on its findings by the evidence cited by the parties to that dispute, this author believes that irrespectively of the finding of such tribunal, there are sufficient grounds to conclude that, although circumvented with controversy, the clean hands doctrine amounts to a general principle of international law. (On the criteria to find the existence of a general principle of international law, see Hugh Thirlway, The Sources of International Law, Oxford University Press, 2014, p. 93-115).

19 See Mamidoil Jetoil Greek Petroleum Products Societe S.A. v. Republic of Albania, ICSID Case No. ARB/11/24, Award (30 March 2015), para 293; Phoenix Action, Ltd. v. Republic of Bulgaria, ICSID Case No. ARB/06/05, Award (15 April 2009), para 101; Gustav F.W. Hamester GmbH \& Co KG v. Republic of Ghana, ICSID Case No. ARB/07/24, Award (18 June 2010), para 123-124; and SAUR International SA Republic of Argentina, ICSID Case No. ARB/04/4, Decision on Jurisdiction and Liability (6 June 2012), para 308.

20 See, for example, Article III, Treaty between United States of America and the Argentine Republic concerning the Reciprocal Encouragement and Protection of Investment; Article 2(2) Agreement on Reciprocal Encouragement and Protection of Investments between the Kingdom of the Netherlands and the Republic of Turkey. 21 Article I, Agreement between the Government of Canada and the Government of the Republic of Argentina for the Promotion of Investments (1993). Available at: http://investmentpolicyhub. unctad.org/IIA. in order to hear the dispute. ${ }^{22}$ The rationale is that an investment made in contravention of the host State law does not qualify as an investment under the definition of the BIT. An example is the decision in Inceysa v. El Salvador, where the tribunal found that Inceysa Vallisoletana, S.L., a company who participated in a bidding process to provide the services of installation, management and operation of mechanical inspection plans for vehicles, had fraudulently misrepresented itself in order to obtain the government contract by providing false documents. ${ }^{23}$ Therefore, given that the El Salvador-Spain BIT required each contracting State to protect investments made "in accordance with its legislation," it found that it had no jurisdiction because Inceysa's investment did not meet the BIT's requirement of legality. ${ }^{24}$

Moreover, some tribunals have held that in absence of a legality requirement in the text of the relevant BIT, the clean hands doctrine is applicable as a general principle of international law. ${ }^{25}$ In Plama v. Bulgaria, the tribunal held that even though the Energy Charter Treaty ("ECT") does not contain a provision requiring the conformity of the investment with the host State law, "granting the ECT's protections to Claimant's investment would be contrary to the principle nemo auditur propriam turpidunem allegans." ${ }^{26}$ Previously, the tribunal had determined that Plama Consortium had misled the Bulgarian Privatization Agency into believing that such company had two

22 This author finds surprising that such approach has emerged under international investment law, since no clear indications were found that the intention of the States when including the phrase "in accordance with the laws" in their BITs was to deny the jurisdiction of the tribunal when confronted with an illegal act in the making or development of the investment. In any case, it is worth noting that there are three possible instances in which a tribunal can determine and decide if the investor has unclean hands: (a) the jurisdictional approach, meaning that a finding that the investor violated the host State's law will bar the tribunal from jurisdiction to hear the dispute; (b) the admissibility approach, meaning that, if it finds a violation of the law of the host State, the tribunal will have to declare that one or more of the claims brought by the investor are inadmissible and (c) the merits approach, which means that an alleged violation of the host State law will be resolved as a question of the merits of the case. See Zachary Douglas, The Plea of Illegality in Investment Treaty Arbitration, supra note 6, p. 177-186.

23 Inceysa Vallisoletana, S.L. v. Republic of El Salvador, supra note 2, para 236.

24 Inceysa Vallisoletana, S.L. v. Republic of El Salvador, supra note 2, para 264.

25 Plama Consortium Ltd. v. Republic of Bulgaria, supra note 2, para 140.

26 Plama Consortium Ltd. v. Republic of Bulgaria, supra note 2, para 143. 
important investors, when in fact it did not. ${ }^{27}$ The tribunal was persuaded that Bulgaria would not have given its consent to the transfer of shares to the Plama Consortium (and hence to the establishment of the investment) if it had known that such company was a cover for an individual with limited financial resources. ${ }^{28}$ Thus, several tribunals have not considered necessary the enshrinement of the clean hands doctrine in the express text of the underlying BIT (or other relevant instrument) in order to apply it. ${ }^{29}$

Furthermore, there have been instances where not only the violation of the law of the host State led a tribunal to apply the clean hands doctrine. ${ }^{30}$ The violation of international law or rules of international public policy can also lead to such result. ${ }^{31}$ For instance, in the context of an International Centre for Settlement of Investment Disputes ("ICSID") arbitration initiated under the provisions of an investment contract, the tribunal found that the claimant's admission of paying a bribe to the President of the host State was a violation of international public policy. ${ }^{32}$ Therefore, the tribunal declared its lack of jurisdiction to hear the dispute. ${ }^{33}$

This background reveals that there is support and recognition that the lawfulness of an investment is a necessary condition for the international protection of an investment. ${ }^{34}$ However, this paper asserts that States should not have an unlimited right to invoke failure to comply with its domestic law (or international law) in

27 Plama Consortium Ltd. v. Republic of Bulgaria, supra note 2, para 133.

28 Plama Consortium Ltd. v. Republic of Bulgaria, supra note 2, para 133.

29 Phoenix Action, Ltd. v. The Czech Republic, supra note 2, para 101. 30 World Duty Free Company Limited v. The Republic of Kenya, supra note 13, para 157; Inceysa Vallisoletana, S.L. v. Republic of El Salvador, supra note 2, para 248; Wena Hotels Ltd. v. Arab Republic of Egypt, ICSID Case No. ARB/98/4, Award (8 December 2000), para 111.

31 World Duty Free Company Limited v. The Republic of Kenya, supra note 13, para 157; Inceysa Vallisoletana, S.L. v. Republic of El Salvador, supra note 2, para 248; Wena Hotels Ltd. v. Arab Republic of Egypt, ICSID Case No. ARB/98/4, Award (8 December 2000), para 111.

32 World Duty Free Company Limited v. The Republic of Kenya, supra note 13, para 157.

33 World Duty Free Company Limited v. The Republic of Kenya, supra note 13 , para 157

34 In Yukos Universal Limited (Isle of Man) v. Russian Federation, the tribunal held that "an investor who has obtained an investment in the host State only by acting in bad faith or in violation of the laws of the host state [...] should not be allowed to benefit from the Treaty." (See Yukos Universal Limited (Isle of Man) v. Russian Federation, supra note 18, para 1352). order to deny such protection. ${ }^{35}$ The idea underlying this proposal has already been insinuated in cases such as SPP v. Egypt. ${ }^{36}$ In that case, the tribunal conceded that a Presidential decree recognizing rights to the investors could be null and void under Egyptian law. However, it recognized that the decree was an act of an Egyptian authority, creating expectations on the investor that were protected by established principles of international law. ${ }^{37}$ Thus, in the next section I propose an analytical framework for investment arbitration tribunals to determine if an investor's particular alleged violation of the host State's law warrants the definitive response of denying protection to an investment.

\section{THE PROPOSED ANALYTICAL FRAMEWORK FOR CASES WHERE THE CLEAN HANDS DOCTRINE IS INVOKED}

There are two factors that an investment arbitration tribunal should take into account when confronted with allegations of unlawful acts committed by an investor in the establishment or development of its investment. These two should apply irrespectively of whether the BIT contains an "in accordance with the law" clause or the clean hands doctrine is understood to amount to a general principle of international law.

First, the tribunal should assess the type and the degree of violation of the law committed by the investor. Second, the relevant tribunal should evaluate the relationship between the investor's wrongdoing and the conduct of the involved State in connection with the alleged unlawful act.

A. Determining the Type of Violations that Justify an Application of the Clean Hands Doctrine

It is no secret that when confronted with a claim by an investor, a State will try to use all the possible legal arguments available in order to avoid its liability which in turn could lead to an obligation to provide

35 See, Aloysius Llamzon, Corruption in International Investment Arbitration, supra note 6, p. 188; Zachary Douglas, The Plea of Illegality in Investment Treaty Arbitration, supra note 6, p. 155; Kevin Lim, Upholding Corrupt Investors' Claims Against Complicit or Compliant Host States Where Angels Should Not Fear to Tread, supra note 6, p. 608.

36 Southern Pacific Properties (Middle East) Limited v. Arab Republic of Egypt, ICSID Case No. ARB/84/3, Award (May 20 1992).

37 Southern Pacific Properties (Middle East) Limited v. Arab Republic of Egypt, ICSID Case No. ARB/84/3, Award (May 20 1992), para 83. 
considerable compensation. ${ }^{38}$ Thus, it is unsurprising that States rely on the clean hands doctrine in order to try to convince the tribunal that the investor should not be granted international protection. ${ }^{39}$ In those cases, the requested consequence is that the tribunal has to declare its lack of jurisdiction to hear the dispute or the inadmissibility of the claim brought by the investor. However, the clean hands doctrine can also ultimately serve as a mechanism to try to convince the tribunal to limit the amount of compensation in favor of an investor. ${ }^{40}$

Not every single infraction of the host State's legal order should lead to a denial of protection. ${ }^{41}$ Although BITs do not provide any standard for the assessment of this issue, several decisions of investment arbitration tribunals offer some light as to which specific situations should lead to an exclusion of investment protection. ${ }^{42}$

The scenarios under which tribunals have found that the clean hands doctrine should be applied - without a doubt - include cases under which the investor has been involved in acts of (i) corruption ${ }^{43}$; (ii) fraud or misrepresentation ${ }^{44}$ or (iii) deliberate violations of legal

38 See, Mytilineos Holdings SAv Serbia and Montenegro and Serbia, UNCITRAL, Partial Award on Jurisdiction (8 September 2006); Inmaris Perestroika Sailing Maritime Services Gmbh and others v Ukraine, ICSID Case No. ARB/08/8, Decision on Jurisdiction (8 March 2010); Tokios Tokelés v. Ukraine, supra note 9; Inceysa Vallisoletana, S.L. v. Republic of El Salvador, supra note 2; Fraport AG Frankfurt Airport Services Worldwide v. Philippines, supra note 2; Phoenix Action, Ltd. v. Republic of Bulgaria, supra note 2; Gustav F.W. Hamester GmbH \& Co KG v. Republic of Ghana, supra note 19.

39 See, Phoenix Action, Ltd. v. The Caech Republic, supra note 2; SAUR International SA v. Republic of Argentina, supra note 19; Quiborax SA and Non-Metallic Minerals SAv Plurinational State of Bolivia, ICSID Case No. ARB/06/2, Decision on Jurisdiction (27 September 2012); Ambiente Ufficio sp $A$ and others v. Argentine Republic, ICSID Case No. ARB/08/9, Decision on Jurisdiction and Admissibility (8 February 2013).

40 Yukos Universal Limited (Isle of Man) v. Russian Federation, supra note 18, para 1607-1637.

41 Zachary Douglas, The Plea of Illegality in Investment Treaty Arbitration, supra note 6, p. 155.

42 See, World Duty Free Company Limited v. The Republic of Kenya, supra note 13; Metal-Tech Ltd v. The Republic of Uzbekistan; supra note 13; Inceysa Vallisoletana, S.L. v. Republic of El Salvador, supra note 2; Plama Consortium Ltd. v. Republic of Bulgaria, supra note 2; Fraport AG Frankfurt Airport Services Worldwide v. Philippines, supra note 2; Rumeli Telekom AS and Telsim Mobil Telekomunikasyon Hirmetleri AS v. Republic of Kazakhastan, ICSID Case No. ARB/05/16, Award (29 July 2008); Desert Line Projects LLC v. Republic of Yemen, ICSID Case No. ARB/05/17, Award (6 February 2008).

43 See, World Duty Free Company Limited v. The Republic of Kenya, supra note 13; Metal-Tech Ltd v. The Republic of Uzbekistan; supra note 13. 44 See, Inceysa Vallisoletana, S.L. v. Republic of El Salvador, supra note 2; Plama Consortium Ltd. v. Republic of Bulgaria, supra note 2. provisions of the host State. ${ }^{45}$

\section{(i) Corruption}

The clean hands doctrine has been recognized to apply when it is proven that the investor was involved in one or several acts of corruption. ${ }^{46}$ This is because corruption has been deemed to be such a wrongful conduct that the responsible party cannot be allowed to resort to international arbitration. ${ }^{47}$ Indeed, the prohibition of corruption has been recognized as an essential rule of the vast majority of legal systems around the world. ${ }^{48}$

In investment arbitration, the paradigmatic case involving corruption is World Duty Free v. Kenya. ${ }^{49}$ In that decision, the arbitral tribunal was very clear in stating that "bribery is contrary to international public policy of most, if not all, States" ${ }^{50}$ The tribunal then determined that it had to declare its lack of jurisdiction after the representative of World Duty Free admitted having paid US $\$ 2$ million to Kenya's President when it obtained the investment contract. $^{51}$

More recently, such approach was again taken in Metal-Tech, Ltd. v. The Republic of Uzbekistan, where the tribunal held that the rights of the investor could not be protected because the investment was contaminated by an illegal activity such as corruption..$^{52}$ Specifically,

45 See, Fraport AG Frankfurt Airport Services Worldwide v. Philippines, supra note 2; Rumeli Telekom AS and Telsim Mobil Telekomunikasyon Hizmetleri AS v. Republic of Kazakhastan, supra note 42.

46 Carolyn B. Lamm, Fraud and Corruption in International Arbitration, supra note 6, p. 720-728; Kevin Lim, Upholding Corrupt Investors' Claims Against Complicit or Compliant Host States - Where Angels Should Not Fear to Tread, supra note 6, p. 605-609.

47 For instance, in Wena Hotels, Ltd. v. Arab Republic of Egypt, the tribunal held that corruption is contrary to international bones mores or international good manners. (Wena Hotels Ltd. v. Arab Republic of Egypt, supra note 30, para 111).

48 Abdulhay Sayed, Corruption in International Trade and Commercial Arbitration, Kluwer Law International, 2004, p. 231-309; Andreas Kulick, Global Public Interest in International Investment Law, Cambridge University Press, 2014, p. 307-309.

49 Interestingly, the tribunal in such case did not explicitly mention the clean hands doctrine. However, it decided to rely on the idea behind such doctrine, namely that an investment obtained through the commission of an unlawful act of fundamental importance, such as corruption, should not be allowed to benefit from international arbitration.

50 World Duty Free Company Limited v. The Republic of Kenya, supra note 13 , para 157.

51 World Duty Free Company Limited v. The Republic of Kenya, supra note 13 , para 179.

52 Metal-Tech Ltd v. The Republic of Uzbekistan; supra note 13, para 389. 
the tribunal stated that "the law is clear - and rightly sothat in such situation the investor is deprived of protection and, consequently, the host State avoids any potential liability." Thus, in such case, Metal-Tech, an Israeli company, was not allowed to invoke its rights under the Israel-Uzbekistan BIT, which contained a reference to the clean hands doctrine when defining an investment as "any kind of assets, implemented in accordance with the laws and regulations of the Contracting Party in whose territory the investment is made." 53

It can certainly be perceived as unfair that an investor is deprived from having access to international arbitration in cases of corruption, where there is always a representative of the State involved in the unlawful transaction. The tribunal in World Duty Free v. Kenya acknowledged this concern. ${ }^{54}$ However, given that tribunals are dealing with such a wrongful conduct with respect to which there is a global interest for its eradication, investors should bear the consequences of being involved in such type of ominous act. The message being sent is that investors should prefer to withdraw from a prospective investment than incur in corruption in order to move forward with their intended business. ${ }^{55}$

\section{(ii) Frand}

Meanwhile, fraud has been understood as a willful misrepresentation of the truth by an investor to induce the State to act in a manner that is detrimental to its interests. ${ }^{56}$ Although a prohibition on fraud has not been as widely recognized as in the case of corruption, there are several cases that identify that in cases of fraud, an investor will be barred from seeking protection before an investment arbitration tribunal. ${ }^{57}$ The rationale behind this determination is simple: the State would never had approved the investment if it would have known the facts misrepresented by the investor. ${ }^{58}$

For instance, the tribunal in Plama v. Bulgaria held

53 Metal-Tech Ltd v. The Republic of Uzbekistan; supra note 13, para 186.

54 World Duty Free Company Limited v. The Republic of Kenya, supra note 13 , para 180.

55 World Duty Free Company Limited v. The Republic of Kenya, supra note 13 , para 181.

56 Inceysa Vallisoletana, S.L. v. Republic of El Salvador, supra note 2, para 102-128.

57 Inceysa Vallisoletana, S.L. v. Republic of El Salvador, supra note 2, para 102-128; Plama Consortium Ltd. v. Republic of Bulgaria, supra note 2, para.143.

58 Inceysa Vallisoletana, S.L. v. Republic of El Salvador, supra note 2, para 102-128. that a fraudulent misrepresentation is prohibited under international public policy. ${ }^{59}$ During the proceedings, Plama contended that it had no obligation to disclose to the Bulgarian government the identity of the real shareholders of the company. ${ }^{60}$ However, the tribunal found that in circumstances under which "the State's approval of the investment was required as a matter of law dependent on the financial and technical qualification of the investor," the investor could not withhold such information from the government. ${ }^{62}$ Therefore, it was held that when materials changes that could have an effect on the host State's approval occur in the investor's shareholding, the investor is obliged to inform the host State of such changes. ${ }^{63}$

Likewise, in Inceysa v. El Salvador, the tribunal determined that the investor also perpetrated a fraudulent misrepresentation by committing several actions in the context of the bidding process to obtain the contract for the installation, management and operation of mechanical inspection plant for vehicles. ${ }^{64}$ Namely, the tribunal found evidence of (i) presentation of false financial information in the tender made to participate in the bid; ${ }^{65}$ (ii) false representations during the bidding process in connection with the experience and capacity that was necessary to comply with the terms of the relevant contract; ${ }^{66}$ (iii) providing false documents ${ }^{67}$ and (iv) hiding the existing relationship between Inceysa and another bidding company. ${ }^{68}$ The tribunal, chaired by Rodrigo Oreamuno Blanco, held that the existence of the phrase "in accordance with law" in Article III of the El Salvador-Spain BIT was a clear manifestation of an international public policy to exclude from protection,

59 Inceysa Vallisoletana, S.L. v. Republic of El Salvador, supra note 2, para 102-128.

60 Plama Consortium Ltd. v. Republic of Bulgaria, supra note 2, para. 145.

61 Plama Consortium Ltd. v. Republic of Bulgaria, supra note 2, para. 145.

62 Plama Consortium Ltd. v. Republic of Bulgaria, supra note 2, para. 145.

63 Plama Consortium Ltd. v. Republic of Bulgaria, supra note 2, para. 145

64 Inceysa Vallisoletana, S.L. v. Republic of El Salvador, supra note 2, para 3.

65 Inceysa Vallisoletana, S.L. v. Republic of El Salvador, supra note 2, para 103.

66 Inceysa Vallisoletana, S.L. v. Republic of El Salvador, supra note 2, para 236.

67 Inceysa Vallisoletana, S.L. v. Republic of El Salvador, supra note 2, para 109.

68 Inceysa Vallisoletana, S.L. v. Republic of El Salvador, supra note 2, para 236. 
investments made in violation of the internal laws of the Contracting States. ${ }^{69}$ Specifically, it stated that:

\begin{abstract}
It is uncontroversial that respect for the law is a matter of public policy not only in El Salvador, but in any civilized country. If this Tribunal declares itself competent to hear the disputes between the parties, it would completely ignore the fact that, above any claim of an investor, there is a metapositive provision that prohibits attributing effects to an act done illegally. ${ }^{70}$
\end{abstract}

Thus, when a tribunal determines that an investor incurred in fraudulent conduct while making its investment, such act constitutes sufficient grounds to deny protection to the investor.

\section{(iii) Deliberate Violation of Legal Provisions}

A deliberate violation of fundamental constitutional or legal provisions has also been recognized by several tribunals to constitute sufficient grounds for the application of the clean hands doctrine. ${ }^{71}$ For example, in Fraport v. The Republic of the Philippines, the tribunal held that the investor was aware of the fact that under Philippine law, foreign citizens were prohibited from intervening in the management, operation or control of public utility companies. ${ }^{72}$ Thus, given that Fraport decided to secretly arrange management and control of the project in a way it knew was not in accordance with Philippine law, it lost its right to have such investment protected as provided in the Germany-Philippines BIT. ${ }^{73}$

Therefore, deliberate violations of constitutional and legal provisions also allow an investment arbitration tribunal to deny protection to an investment. In this case, the emphasis has to be put in analyzing whether the breach of the host State's law was indeed deliberate. That is, if the investor was aware that its course of action clearly contravened the legal order of the State where it was making its investment, yet decided to move forward with the illegal course of action.

As we will be explained infra, absent corruption, fraud or a deliberate violation of the law, investment

69 Inceysa Vallisoletana, S.L. v. Republic of El Salvador, supra note 2, para 246

70 Inceysa Vallisoletana, S.L. v. Republic of El Salvador, supra note 2, para 248.

71 See, Fraport AG Frankfurt Airport Services Worldwide v. Philippines, supra note 2.

72 Fraport AG Frankfurt Airport Services Worldwide v. Philippines, supra note 2, para 327.

73 Fraport AG Frankefurt Airport Services Worldwide v. Philippines, supra note 2, para 401. arbitration tribunals should assess the degree of importance of the legal provision violated by the investor. This would allow the tribunal to determine if the investment should be denied protection or if the claims should be admitted. If the claims are admitted, further assessment of the unlawful act can be carried out in the merits phase of the dispute. This is because as held by the tribunal in Fraport v. The Republic of the Philippines, "when the question is whether the investment is made in accordance with the law of the host State, considerable arguments may be made in favor of construing jurisdiction in a more liberal way which is generous to the investor." Thus, such tribunal recognized that there might be circumstances under which the law in question of the host State may not be entirely clear and mistakes may be made in good faith at the moment of the acquisition of the investment. ${ }^{75}$ For instance, in the words of the tribunal chaired by Yves Fortier, admissible errors could be the failure of competent local counsel to flag certain legal issues or that the arrangement infringing the host State's law was not central to the profitability of the investment. ${ }^{76}$ All those exceptions were deemed not applicable in favor of Fraport since the company willfully violated the prohibitions set forth in Philippines law in relation to foreign control of public utility companies. ${ }^{77}$ Such approach is relevant when the issue before the tribunal is whether it has jurisdiction. Thus, even when an illegality occurred, such event can be subsequently taken into account by the tribunal when assessing the merits of the dispute, especially when calculating the damages, if applicable, in favor of the investor. ${ }^{78}$

\section{B. Fundamental Versus Minor Violations of the Host} State's Law

The different examples of unlawful conducts that we have described above qualify automatically as fundamental violations of any domestic legal order. Acts of corruption, fraudulent misrepresentation and willful violation of fundamental constitutional and legal provisions are all reproachable acts that an investor

74 Fraport AG Frankfurt Airport Services Worldwide v. Philippines, supra note 2, para 396.

75 Fraport AG Frankfurt Airport Services Worldwide v. Philippines, supra note 2, para 396.

76 Fraport AG Frankefurt Airport Services Worldwide v. Philippines, supra note 2, para 396.

77 Fraport AG Frankfurt Airport Services Worldwide v. Philippines, supra note 2, para 396.

78 Fraport AG Frankfurt Airport Services Worldwide v. Philippines, supra note 2, para 396. 
should not commit when acquiring or developing its investment. Absent involvement or acquiescence of the State in the unlawful conduct, the result in these types of cases should be that the investor's investment is not awarded protection.

In contrast, minor violations of the host State's law should not lead to a denial of investment protection. Therefore, when not dealing with acts of corruption, fraud or deliberate violations of the law, investment arbitration tribunals should consider the degree of the infringement to the host State's law as the criterion to assess whether the clean hands doctrine is an admissible defense for a State. Such conclusion has been affirmed in cases such as Rumeli v. Republic of Karakbstan, where the tribunal held the following: To defeat the Tribunal's jurisdiction based on a BIT's requirement that the disputed investments be in conformity with the host State's laws and regulations, a certain level of violation is required. As determined by the Arbitral Tribunal in the Lesi [v. Algeria] case, such a provision will exclude the protection of investments only if they have been made in breach of fundamental legal principles of the host country. ${ }^{79}$

Furthermore, the tribunal in Desert Line Projects LLC v. The Republic of Yemen explained that the phrase "in accordance with law" found in several BITs is a reference intended to ensure the legality of the investment by excluding investments "made in breach of fundamental principles of the host State's law, e.g. by fraudulent misrepresentations or the dissimulation of true ownership." ${ }^{\circ 0}$ Given that in that case Yemen had neither alleged nor proven such type of illegality, the tribunal upheld its jurisdiction. ${ }^{81}$

Investment arbitration tribunals have also recognized that certain violations of the host State law are not of sufficient degree for the purpose of applying the clean hands doctrine. ${ }^{82}$ For instance, in Metalpar v. Argentina, the investor failed to register the company documents at the appropriate time, despite a provision under Argentinian law to the contrary. ${ }^{83}$ Argentina ar-

79 Rumeli Telekom AS and Telsim Mobil Telekomunikasyon Hizmetleri AS v. Republic of Kazakhastan, supra note 42, para 168.

80 Desert Line Projects LLC v. Republic of Yemen, supra note 42, para 104.

81 Desert Line Projects LLC v. Republic of Yemen, supra note 42, para 105.

82 Metalpar S.A. and Buen Aire S.A. v. The Argentine Republic, ICSID Case No. ARB/03/5, Decision on Jurisdiction (27 April 2006). 83 Metalpar S.A. and Buen Aire S.A. v. The Argentine Republic, ICSID Case No. ARB/03/5, Decision on Jurisdiction (27 April 2006, gued that the consequence of such violation had to be the denial of access to ICSID arbitration for Metalpar, S.A. ${ }^{84}$ However, the tribunal rejected that contention highlighting that Argentinian law already prescribed sanctions for such violation and that to deny investment protection would be disproportionate. ${ }^{85}$ Specifically, the tribunal explained that:

[...] the lack of timely registration could be sanctioned by a denial of the inscription of certain documents of the company or its officials, but it would be disproportionate to punish this omission with denying an investor an essential protection as the access to ICSID arbitration. Additionally, it would be illogical to admit that certain behavior (the lack of timely registration) for which the Argentinean legal system provides for specific sanctions could be punished, additionally, in other forms not provided for in that legal order. ${ }^{86}$

The tribunal in Tokios Tokeles v. Ukraine arrived to a similar finding. Ukraine had argued that the investment was not made in accordance with Ukrainian law, as required by the Ukraine - Lithuania BIT. ${ }^{87}$ The argument was that the full name under which Tokios Tokeles registered its subsidiary was improper because it referred to a "subsidiary private enterprise" which is not a recognized legal form under Ukrainian law. ${ }^{88}$ Despite that error, the government authorities registered Tokios Tokelès' subsidiary as a valid enterprise and over the next eight years, also registered each of its investments in Ukraine. ${ }^{89}$ Thus, the tribunal held that "to exclude an investment on the basis of such minor errors would be inconsistent with the object and purpose of the Treaty." 90

As can be seen, the core issue for a tribunal confronted with an act of an investor that could be deemed as an infringement of the host State's law is whether such unlawful conduct amounts to a fundamental or a minor violation. ${ }^{11}$

\section{para 84.}

84 Metalpar S.A. and Buen Aire S.A. v. The Argentine Republic, ICSID Case No. ARB/03/5, Decision on Jurisdiction (27 April 2006, para 82.

85 Metalpar S.A. and Buen Aire S.A. v. The Argentine Republic, ICSID Case No. ARB/03/5, Decision on Jurisdiction (27 April 2006, para 84.

86 Metalpar S. A. and Buen Aire S. A. v. The Argentine Republic, ICSID Case No. ARB/03/5, Decision on Jurisdiction (27 April 2006, para.

87 Tokios Tokelés v. Ukeraine, supra note 9, para 83.

88 Tokios Tokelés v. Ukeraine, supra note 9, para 83.

89 Tokios Tokelés v. Ukeraine, supra note 9, para 86.

90 Tokios Tokelés v. Ukraine, supra note 9, para 86.

91 See, Metalpar S.A. and Buen Aire S.A. v. The Argentine Republic, supra note 82; Desert Line Projects LLC v. Republic of Yemen, supra note 42; Rumeli Telekom AS and Telsim Mobil Telekomunikasyon Hizmetleri 
Consequently, an investment arbitration tribunal should only deny protection to an investment by declaring its lack of jurisdiction in cases of fundamental violations of the host State's law. The obvious cases of fundamental violations are acts of corruption, fraud and deliberate violations of constitutional and legal provisions of the involved State's legal order. Obviously, apart from those cases, it becomes more difficult to distinguish between fundamental and minor violations of the law.

Although a final determination in relation to this issue could be highly dependent on the specific facts of each case and the arguments made by the parties, ${ }^{92}$ there are two elements that could be taken into account in order to draw a distinction. First, if the unlawful conduct is deemed to be a violation of international public policy. ${ }^{93}$ An example of this case would be when an investor uses children as employees. ${ }^{94}$ Presumably, when the violation of a regulation amounts to a violation of international public policy it is also a core provision of the municipal legal order. ${ }^{95}$ Thus, when the unlawful act is also a violation of international public policy, such fact could be a good indicator that the illegality is one of fundamental character. ${ }^{96}$ Second, in these types of situations, the tribunal should give greater consideration to the principle of proportionality. ${ }^{97}$ For instance, in $\mathrm{Me}$ talpar v. Argentina, the tribunal assessed the proportionality between the specific unlawful conduct (lack of timely registry of corporate documents) and the possible sanction of depriving the investor from protection..$^{98}$

AS v. Republic of Kazakhastan, supra note 42; Tokios Tokelés v. Ukraine, supra note 9.

92 Mamidoil Jetoil Greek Petroleum Products Societe S.A. v. Republic of Albania, supra note 19, para 294.

93 Pierre Laclive, Transnational (Or Truly International) Public Policy, VIII International Congress on Arbitration, ICCA, Congress Series, 1986, Kluwer, The Hague, p. 295; Martin Hunter and Gui Conde E Silva, Transnational Public Policy and its Application in Investment Arbitrations, The Journal of World Investment, Volume 4, No. 3, 2003, p. 367-378.

94 Vid Prislan and Ruben Zandvliet, Labor Provisions in International Investment Agreements: Prospects for Sustainable Development, Yearbook of International Investment Law and Policy 2012-2013, Oxford University Press, 2013, p. 52.

95 Inceysa Vallisoletana, S.L. v. Republic of El Salvador, supra note 2, para 246.

96 Inceysa Vallisoletana, S.L. v. Republic of El Salvador, supra note 2, para 246.

97 Prabhash Ranjan, Using the Public Law Concept of Proportionality to Balance Investment Protection with Regulation in International Investment Law: A Critical Appraisal, Cambridge Journal of International and Comparative Law, Volume 3, No. 3, 2014, p. 853-883.

98 Metalpar S.A. and Buen Aire S.A. v. The Argentine Republic, supra
It ultimately held that it would be disproportionate to deny protection for such type of violation..$^{99}$ Therefore, in order to distinguish between fundamental and minor violations a tribunal could assess whether proportionality between the alleged unlawful conduct and the existing sanctions for such conduct under the host State's law. ${ }^{100}$ This is a path that requires further study from scholars and tribunals.

C. Involvement or Acquiescence in the Commission of the Assessed Unlawful Act: A Justiffing Cause for Bypassing the Application of the Clean Hands Doctrine in the Jurisdictional Phase of the Dispute

On the other hand, even in cases of corruption, fraud or deliberate violations of the law, investment arbitration tribunals should take into account the involvement or acquiescence of the relevant State in the unlawful conduct committed by the investor. This section argues that when a tribunal finds that the host State was involved or acquiesced to the alleged unlawful conduct, there are, per se, sufficient legal grounds to bypass the application of the clean hands doctrine in (at least) the jurisdictional phase of the dispute.

\section{(i) Involvement}

There are cases in which the host State (through its officials ${ }^{101}$ ) is involved in the commission of the unlawful acts being now attributed to the investor in the arbitration proceedings. Such officials, acting under the cloak of governmental authority, could have led the investor to believe that their conduct was lawful or in any case, that the commission of such act was necessary for the purposes of establishing or further developing the investment.

In such cases, I propose that the State should be estopped from invoking such unlawful conduct for the purposes of trying to deny protection to the investment. This is because the host State, having misled the inves-

note 82 , para 84.

99 Metalpar S.A. and Buen Aire S.A. v. The Argentine Republic, supra note 82 , para 84 ..

100 Metalpar S.A. and Buen Aire S.A. v. The Argentine Republic, supra note 82 , para 84 ..

101 The author is aware that the question of the involvement or acquiescence of the State in an unlawful conduct will entail an exam on attribution. This paper does not seek to assess the legal questions that might arise in such area. In any case, the author recommends the following study, which although limited to cases of corruption, deals in detail with the most important questions in that regard. See Aloysius Llamzon, Corruption in International Investment Arbitration, supra note 6; p. 238-281. 
tor by behaving as it did agree with the alleged unlawful conduct, should not be permitted to deny the conclusion that its conduct suggested. ${ }^{102}$ In short, this leads to the application of the principle of estoppel, which in the words of the International Court of Justice:

\begin{abstract}
Is a principle that operates to prevent a State from contesting before a Court a situation contrary to a clear and unequivocal representation previously made to its counterparty, either expressly or impliedly, on which representation that counterparty was, in the circumstances, entitled to rely and in fact did rely, and as a result that other party has been prejudiced or the State making it has secured some benefit or advantage for itself. ${ }^{103}$
\end{abstract}

In Kardassopoulos v. Georgia, for instance, the State argued that the tribunal did not have jurisdiction ratione materiae under the ECT provisions and the relevant BIT since a joint venture agreement and a concession between the investor and two State-owned enterprises were void under Georgian law. ${ }^{104}$ However, Claimants contended that representations made by the State-owned companies created a legitimate expectation regarding the validity of the joint venture agreement and the concession. ${ }^{105}$ For example, Claimants relied on the fact that Article 2.1 of the joint venture agreement provided that the joint venture was established "in accordance with the provisions of the legislation for Joint Ventures". ${ }^{106}$ More importantly, the tribunal focused on the assurances given to the investor regarding the validity of the joint venture agreement and the concession, which were endorsed by the government through some of the most senior government officials, who were also closely involved in the negotiation of both instruments. ${ }^{107}$ In consequence, the tribunal held that Georgia's position was unsustainable. ${ }^{108}$ It explained that the principle of attribution was applicable and re-

102 H.W.A. Thirlway, The Law and Procedure of the International Court of Justice, British Yearbook of International Law, Volume 60, 1989, p. 29; Ian Sinclair, Estoppel and Acquiescence, Fifty Years of the International Court of Justice: Essays in Honour of Sir Robert Jennings, Cambridge University Press, 2007, p. 105.

103 Temple of Preah Vihear (Cambodia v Thailand), Merits, 1962, ICJ Reports 101, para 143-144.

104 Ioannis Kardassopoulos v. The Republic of Georgia, ICSID Case No. ARB/05/18, Decision on Jurisdiction (6 July 2007), para 191.

105 Kardassopoulos v. The Republic of Georgia, supra note 104, para 185.

106 Kardassopoulos v. The Republic of Georgia, supra note 104, para

185.

107 Kardassopoulos v. The Republic of Georgia, supra note 104, para

191.

108 Kardassopoulos v. The Republic of Georgia, supra note 104, para

190. lied on the fact that Article 7 of the Articles of State Responsibility stipulates that "even in cases where an entity empowered to exercise governmental authority acts ultra vires, the conduct in question is nevertheless attributable to the State." 109

Thus, the involvement of the State in the commission of the unlawful conduct (by for example entering into an agreement or even encouraging the investor to commit an unlawful conduct) should prevent the State from raising such illegality as defense against the investor's claims. Such conclusion was recognized by the tribunal in Fraport v. The Republic of the Philippines, which held that:

[...] Principles of fairness should require a tribunal to hold a government estopped from raising violations of its own law as a jurisdictional defense when it knowingly overlooked them and endorsed an investment which was not in compliance with its law. ${ }^{110}$

Therefore, a State should be estopped from invoking unlawful conduct committed by the investor when the State itself, through its representatives, was involved in the commission of such conduct. Some ${ }^{111}$ have argued that the doctrine of estoppel is inapplicable since as provided for example in Pan American v. Argentina, ${ }^{112}$ its application requires (i) a clear statement of fact; (ii) which is voluntary, unconditional, and authorized; and (iii) is relied on to the other party's detriment. ${ }^{113}$ However, this thesis fails since estoppel is not limited only to statements of facts but it can also arise from the conduct of one of the parties involved. ${ }^{114}$ Also, a State, through its officials, can act voluntarily, unconditionally and in an authorized manner. Obviously, an investor can rely on the conduct of the State. ${ }^{115}$

109 Kardassopoulos v. The Republic of Georgia, supra note 104, para 190.

110 Fraport AG Frankfurt Airport Services Worldwide v. Philippines, supra note 2, para 346.

111 See, Brody Greenwald, The Viability of Corruption Defenses in Investment Arbitration When the State Does Not Prosecute, supra note 6.

112 Pan American Energy LLC and BP Argentina Exploration Company v. The Argentine Republic, ICSID Case No. ARB/03/13, Decision on Preliminary Objections (27 July 2006), para 160.

113 Temple of Preah Vibear (Cambodia v Thailand), supra note 103, para 150.

114 Christian Tams, Waiver, acquiescence, and extinctive prescription, in James Crawford, Alain Pellet, and Simon Olleson, eds., The Law of International Responsibility, Oxford University Press, 2010, p. 1044; John Cartwright, Protecting Legitimate Expectations and Estoppel in English Law, Report to the XVII International Congress of Comparative Law, Electronic Journal of Comparative Law, Volume 10.3, 2006.

115 Kevin Lim, Upholding Corrupt Investors' Claims Against Complicit or Compliant Host States - Where Angels Should Not Fear to Tread, supra 


\section{(ii) Acquiescence}

Likewise, if a State is aware of an unlawful act committed solely by the investor but does not respond to it with the available legal mechanisms provided by its legal order, it should also be barred from the possibility of invoking the clean hands doctrine. ${ }^{116}$ In this case, I argue that the involved State is estopped by its acquiescence in relation to the alleged unlawful conduct. In this sense, the jurisprudence of the International Court of Justice has shown that silence or lack of protest maintained over a significant period of time, may be treated as tacit recognition or acquiescence in a position taken by the other party. ${ }^{117}$ However, it is important to highlight that for the silence to constitute an acceptance of a specific factual or legal matter, the State must have had knowledge of the facts against which it refrained from making a protest or acting. ${ }^{118}$

Furthermore, several investment arbitration tribunals have already recognized the possibility of a State acquiescing to unlawful conduct. For instance, in the case of Tokios Tokelés $v$. Ukeraine, the tribunal acknowledged that Ukraine had registered Tokios Tokelés' subsidiary as a valid enterprise in 1994, and over the next eight years, registered each of such company's investments in Ukraine, as was shown in numerous official documents. ${ }^{119}$ However, Ukraine tried to argue that such investments could not be protected since they were made in contravention to Ukrainian law. ${ }^{120}$ But the tribunal held that even assuming that Ukraine's allegations were true, the fact that such investments were duly registered and the relevant governmental entity never invoked any

note 6, para 139-146; Tokios Tokelés $v$. Ukraine, supra note 9, para 86; Ioannis Kardassopoulos $v$. The Republic of Georgia, supra note 104, para 185.

116 In this scenario, we are not only referring to an obligation to prosecute, which in some States is not discretionary to the corresponding authorities. For instance, a State, through the corresponding authorities could also initiate the corresponding administrative sanctioning proceeding after learning of a particular violation to the law.

117 Gulf of Maine (Canada v United States of America), ICJ Reports 1984, para 130; Ian Sinclair, Estoppel and Acquiescence, Fifty Years of the International Court of Justice: Essays in Honour of Sir Robert Jennings, Cambridge University Press, 2007, p. 116; D.W. Bowett, Estoppel before International Tribunals and its Relation to Acquiescence, British Yearbook of International Law, Volume 33, 1957, p. 198.

118 Malcolm Shaw, International Law, Cambridge University Press, 2003, p. 437; I.C. MacGibbon, The Scope of Acquiescence in International Law, British Yearbook of International Law, 1954, p. 143.

119 Tokios Tokelés $v$. Ukraine, supra note 9, para 86.

120 Tokios Tokelés $v$. Ukraine, supra note 9, para 83. defects, clearly indicated that Tokios Tokelés had made an investment in accordance with the laws and regulations of Ukraine. ${ }^{121}$

Even more on point is the decision in Tecmed v. Mexi$c o$, where the tribunal did not accept Mexico's argument on some alleged irregularities committed by the investor in the operation of a waste disposal facility. ${ }^{122}$ The tribunal took into special consideration the fact that the environmental authorities were aware of such alleged infringements but did not act to inform the investor that the irregularities might jeopardize the renewal of the relevant permit. ${ }^{123}$ Moreover, the investor was never sanctioned for such irregularities by the Mexican authorities. ${ }^{124}$ Thus, the tribunal held that those violations of the environmental regulations could not be a justification for denying a renewal of a permit. ${ }^{125}$

In the case of Desert Line v. Yemen, Yemen argued that the tribunal did not have jurisdiction ratione materiae since the Yemen General Investment Authority never issued the required investment certificate to the investor. ${ }^{126}$ Nevertheless, the tribunal found that the lack of investment certificate could not be raised by Yemen in order to deny the jurisdiction of the tribunal. ${ }^{127}$ This was because the investment enjoyed general endorsement from the highest levels of authorities of the government and a Yemenite Vice Primer Minister even had extended certain benefits to Desert Line's investment pursuant to the Yemenite Investment Law. ${ }^{128}$ Thus, the tribunal held that such State had waived the certificate requirement and could not rely on the lack of such certificate for the purposes of denying jurisdiction. ${ }^{129}$

Thus, these decisions referred above allow to conclude that if a State knowingly overlooks a failure to

121 Tokios Tokelés v. Ukraine, supra note 9, para 86.

122 Técnicas Medioambientales Tecmed, S.A. v. The United Mexican States, supra note 9, para 151.

123 Técnicas Medioambientales Tecmed, S.A. v. The United Mexican States, supra note 9, para 151.

124 Técnicas Medioambientales Tecmed, S.A. v. The United Mexican States, supra note 9, para 151.

125 Técnicas Medioambientales Tecmed, S.A. v. The United Mexican States, supra note 9, para 151.

126 Desert Line Projects LLC v. Republic of Yemen, supra note 42, para 92.

127 Desert Line Projects LLC v. Republic of Yemen, supra note 42, para 117.

128 Desert Line Projects LLC v. Republic of Yemen, supra note 42, para 119.

129 Desert Line Projects LLC v. Republic of Yemen, supra note 42, para 121. 
comply or endorses an investment even though it is not in compliance with its laws, such violations of the host State's law should not serve as sufficient grounds to deny the jurisdiction of the arbitral tribunal.

\section{Summary of the Proposed Analytical Framework:}

- In cases of corruption, fraud or deliberate violation of provisions of the host State's law, the arbitral tribunal should proceed to assess the involvement or acquiescence of the State in relation to the unlawful conduct. Only when the relevant State was neither involved nor acquiesced, the arbitral tribunal should declare its lack of jurisdiction.

- When the violation of the host State's law does not amount to an act of corruption, fraud or deliberate violation of the host State's law, the tribunal should assess whether the alleged violation is of fundamental or minor character. If the violation is of fundamental character, the tribunal should evaluate the possible involvement or acquiescence of the State. If present, then it should declare that it has jurisdiction and proceed to assess the merits of the dispute. If there is no involvement or acquiescence of the State, the arbitral tribunal should declare its lack of jurisdiction. Furthermore, if the provision violated is not of fundamental character, the arbitral tribunal should declare it has jurisdiction and proceed to the merits.

- If the arbitral tribunal decides to proceed to the merits of the dispute, such determination does not bar the power of the tribunal to assess the alleged violation of the host State's law in the merits phase of the dispute. Such evaluation could lead, for instance, to the application of a contributory fault standard ${ }^{130}$, thus limiting the amount of compensation due to the investor. ${ }^{131}$

\section{Final considerations}

As described in the introduction, a host State can argue that the investor should not be allowed to proceed

130 Yukos Universal Limited (Isle of Man) v. Russian Federation, supra note 18, para 1637.

131 Yukos Universal Limited (Isle of Man) v. Russian Federation, supra note 18, para 1637. with its claims since in the establishment (or development) of the investment, the investor contravened the host State's law. We will continue to see such allegations in the investor-State dispute settlement arena, either because the relevant treaty requires that an investment is made in accordance with the host State law or because States argue that the clean hands doctrine constitutes a general principle of international law.

The proposal that this paper submits is that an arbitral tribunal should uphold that defense only in a very limited circumstance: when the alleged violation is of fundamental character (which includes cases of corruption, fraud and deliberate violations of the host State's law) and the State is neither involved nor acquiesced to the commission of such conduct. In every other case, the tribunal should declare that it has jurisdiction and proceed to merits phase of the dispute. This is the approach that arbitrators should take in order to reach a decision in relation to an invocation of the clean hands doctrine when assessing their jurisdiction. In any case, that is not to say that the arbitration tribunals cannot assess the alleged unlawful act in the merits phase of the dispute. In fact, such assessment could ultimately lead to a limitation of the compensation to be awarded to the investor.

This proposed analytical framework is restrained because it emerges from the rationale provided by previous decisions of investment arbitration tribunals. Those decisions have recurrently recognized that a State is entitled to have the expectation that the investments made and carried out in its territory will comply with the corresponding laws and regulations. ${ }^{132}$ However, as shown, several tribunals have also acknowledged that it is simply not right to deprive an investment of protection when the State - acting through its agents - is involved or acquiesced to the unlawful conduct.

This is a modest effort to clarify what should be the proper scope and effect of the clean hands doctrine in investment arbitration. The motivation behind it is for it to lead to fair results in the investor-State dispute settlement arena. The ultimate purpose is to allow continued promotion of international cooperation in an environment of respect for the rule of law, key ingredients in the achievement of the economic development that remains elusive in many parts of the world.

132 Mamidoil Jetoil Greek Petroleum Products Societe S.A. v. Republic of Albania, supra note 19, para 291. 


\section{ReferenCES}

Abdulhay Sayed, Corruption in International Trade and Commercial Arbitration, Kluwer Law International, 2004.

Aloysius Llamzon, Corruption in International Investment Arbitration, Oxford University Press, 2014; p. 238-281 and p. 493-513.

Aloysius Llamzon, The State of the "Unclean Hands" Doctrine in International Investment Law: Yukos as both Omega and Alpha, ICSID Review (Spring 2015) 31 (1), p. 1-15.

Alison Ross, Should "clean hands" be a factor in investment arbitration?, Global Arbitration Review, October 30, 2009, Available at: http://globalarbitrationreview.com/news/ article/19249/

Ambiente Ufficio sp $A$ and others v. Argentine Republic, ICSID Case No. ARB/08/9, Decision on Jurisdiction and Admissibility (8 February 2013).

Andrea J. Menaker, The Determinative Impact of Frand and Corruption on Investment Arbitrations, ICSID Review (2010) 25 (1), p. 67-75.

Andreas Kulick, Global Public Interest in International Investment Law, Cambridge University Press, 2014.

Andrew D. Mitchell, M. Sornarajah and Tania Voon, Good Faith and International Economic Law, Oxford University Press, 2015, p. 29-30.

Bernardo Cremades, Corruption and Investment Arbitration, in Global Reflections on International Law, Commerce and Dispute Resolution: Liber Amicorum in Honour of Robert Briner, Gerald Aksen et al eds., 2005, p. 203.

Bernardo M. Cremades, Investment Protection and Compliance with Local Legislation, ICSID Review (2009) 24 (2); p 557-564.

Bin Cheng, General Principles of Law as Applied by International Courts and Tribunals, Cambridge University Press, 1994, p. 155.

Brody Greenwald, The Viability of Corruption Defenses in Investment Arbitration When the State Does Not Prosecute, EJIL: Talk! Blog of the European Journal of International Law, April 15, 2015, Available at: http:/ /www.ejiltalk. org/the-viability-of-corruption-defenses-in-investmentarbitration-when-the-state-does-not-prosecute/

Carolyn B. Lamm, Brody K. Greenwald, and Kristen M. Young, From World Duty Free to Metal-Tech: A Review of International Investment Treaty Arbitration Cases Involving Allegations of Corruption, ICSID Review (Spring 2014) 29 (2), p 328-349.

Carolyn B. Lamm, Hansel T. Pham, and Rahim Moloo, Frand and Corruption in International Arbitration, in M.A. Fernandez-Ballesteros and David Arias, Liber Amicorum Bernardo Cremades, Wolters Kluwer, 2010, p. 711-715.

Case Concerning the Diversion of Water from the River Meuse (Netherlands v. Belgium), Separate Opinion of Judge Hudson, Judgment of 28 June 1937, PCIJ Series A/B, No. 70 .

CDC Group, Code of Responsible Investing, available at: www. cdcgroup.com/PageFiles/149/cdcinvestmentcode.pdf.

Christian Tams, Waiver, acquiescence, and extinctive prescription, in James Crawford, Alain Pellet, and Simon Olleson, eds., The Law of International Responsibility, Oxford University Press, 2010.

Dering v. Earl of Winchelsea, (1787) 29 Eng. Rep. 1184 (Ch.) 1186; 1 Cox Eq. Cas. 318, 319-20.

Desert Line Projects LLC v. Republic of Yemen, ICSID Case No. ARB/05/17, Award (6 February 2008).

Fraport AG Frankfurt Airport Services Worldwide v. Philippines, ICSID Case No. ARB/03/25, Award (16 August 2007).

Gustav F.W. Hamester GmbH \& Co KG v. Republic of Ghana, ICSID Case No. ARB/07/24, Award (18 June 2010).

H.W.A. Thirlway, The Law and Procedure of the International Court of Justice, British Yearbook of International Law, Volume 60, 1989, p. 29.

Hugh Thirlway, The Sources of International Law, Oxford University Press, 2014.

Ian Brownlie, Principles of Public International Law, Oxford University Press, 2008, p. 503.

Ian Sinclair, Estoppel and Acquiescence, Fifty Years of the International Court of Justice: Essays in Honour of Sir Robert Jennings, Cambridge University Press, 2007.

Inceysa Vallisoletana, S.L. v. Republic of El Salvador, ICSID Case No. ARB/03/26, Award (2 August 2006).

Inmaris Perestroika Sailing Maritime Services Gmbh and others $v$ Ukraine, ICSID Case No. ARB/08/8, Decision on Jurisdiction (8 March 2010).

Ioannis Kardassopoulos v. The Republic of Georgia, ICSID Case No. ARB/05/18, Decision on Jurisdiction (6 July 2007), 
James Crawford, Brownlie's Principles of Public International Law, Oxford University Press, 2012, p. 420-421

Joe Tirado, Matthew Page, and Daniel Meagher, Corruption Investigations by Governmental Authorities and Investment Arbitration: An Uneasy Relationship, ICSID Review (Spring 2014) 29 (2), p. 493-513.

John Cartwright, Protecting Legitimate Expectations and Estoppel in English Law, Report to the XVII International Congress of Comparative Law, Electronic Journal of Comparative Law, Volume 10.3, 2006.

Kevin Lim, Upholding Corrupt Investors' Claims Against Complicit or Compliant Host States - Where Angels Should Not Fear to Tread, Yearbook on International Investment Law and Policy 2011-2012, Oxford University Press, p. 601-679.

Mamidoil Jetoil Greek Petroleum Products Societe S.A. v. Republic of Albania, ICSID Case No. ARB/11/24, Award (30 March 2015).

Martin Hunter and Gui Conde E Silva, Transnational Public Policy and its Application in Investment Arbitrations, The Journal of World Investment, Volume 4, No. 3, 2003, p. 367-378.

Metal-Tech Ltd v. The Republic of Uzbekistan, ICSID Case No. ARB/10/3, Award (4 October 2013).

Metalpar S. A. and Buen Aire S.A.v. The Argentine Republic, ICSID Case No. ARB/03/5, Decision on Jurisdiction (27 April 2006).

Mohamed Abdel Raouf, How Should International Arbitrators Tackle Corruption Issues?, ICSID Review (2009) 24 (1), p. 116-136.

Mytilineos Holdings SA v Serbia and Montenegro and Serbia, UNCITRAL, Partial Award on Jurisdiction (8 September 2006).

Niko Resources Ltd. v. Bangladesh, ICSID Case No. ARB/10/11, Decision on Jurisdiction (19 August 2013), para 477.

Pan American Energy LLC and BP Argentina Exploration Company v. The Argentine Republic, ICSID Case No. ARB/03/13, Decision on Preliminary Objections (27 July 2006).

Pierre Laclive, Transnational (Or Truly International) Public Policy, VIII International Congress on Arbitration, ICCA, Congress Series, 1986, Kluwer, The Hague.
Plama Consortium Ltd. v. Republic of Bulgaria, ICSID Case No. ARB/03/24, Award (27 August 2008).

Phoenix Action, Ltd. v. The Czech Republic, ICSID Case No. ARB/06/5, Award (15 April 2009).

Prabhash Ranjan, Using the Public Law Concept of Proportionality to Balance Investment Protection with Regulation in International Investment Law: A Critical Appraisal, Cambridge Journal of International and Comparative Law, Volume 3, No. 3, 2014.

Quiborax $S A$ and Non-Metallic Minerals $S A v$ Plurinational State of Bolivia, ICSID Case No. ARB/06/2, Decision on Jurisdiction (27 September 2012).

Rahim Moloo, A Comment on the Clean Hands Doctrine in International Law, TDM 1 (2011); Available at: www. transnational-dispute-management.com.

Richard Kleindler, Corruption in International Investment Arbitration: Jurisdiction and the Unclean Hands Doctrine, in Between East and West: Essays in Honour of Ulf Franke, Kaj Hobér et al eds., Juris, 2010, p. 309-327.

Rumeli Telekom AS and Telsim Mobil Telekomunikasyon Hizmetleri AS v. Republic of Kazakhastan, ICSID Case No. ARB/05/16, Award (29 July 2008).

SAUR International SA v. Republic of Argentina, ICSID Case No. ARB/04/4, Decision on Jurisdiction and Liability (6 June 2012).

Southern Pacific Properties (Middle East) Limited v. Arab Republic of Egypt, ICSID Case No. ARB/84/3, Award (May 20 1992).

T. Leigh Anenson, Limiting Legal Remedies: An Analysis of Unclean Hands, Kentucky Law Journal, Vol. 99, 2010, p. 63-64.

Técnicas Medioambientales Tecmed, S.A. v. The United Mexican States, ICSID Case No. ARB(AF)/00/2, Award (29 May 2003).

Temple of Preah Vihear (Cambodia v Thailand), Merits, 1962, ICJ Reports 101, para 143-144.

Tokios Tokelés v. Ukraine, ICSID Case No. ARB/02/18, Decision on Jurisdiction (29 April 2004).

Vid Prislan and Ruben Zandvliet, Labor Provisions in International Investment Agreements: Prospects for Sustainable Development, Yearbook of International Investment Law and Policy 2012-2013, Oxford University Press, 2013. 
Wena Hotels Ltd. v. Arab Republic of Egypt, ICSID Case No. ARB/98/4, Award (8 December 2000).

World Duty Free Company Limited v. The Republic of Kenya, ICSID Case No. ARB/00/7, Award (4 October 2006)

Yukos Universal Limited (Isle of Man) v. Russian Federation (See Hulley Enterprises Limited (Cyprus), Veteran Petroleum
Limited (Cyprus) and Yukos Universal Limited (Cyprus) v. Russian Federation, PCA Case No. AA226-28, Final Awards (18 July 2014).

Zachary Douglas, The Plea of Illegality in Investment Treaty Arbitration, ICSID Review (Winter 2014) 29 (1), p. 155186. 
Para publicar na Revista de Direito Internacional, acesse o endereço eletrônico www.rdi.uniceub.br ou www.brazilianjournal.org.

Observe as normas de publicação, para facilitar e agilizar o trabalho de edição. 